\title{
3.2 Developing Regional Social Innovation ECOSYSTEMS
}

\author{
Dmitri DoMANSKI \\ TU Dortmund University
}

\section{Social innovation research as a young and dynamic field}

Although we can find scientific publications on social innovation dating back to the 19th century, it has only become an autonomous research field in recent years. For a long time, it was a matter of loosely - if at all - connected research efforts rather than of an area with common research interests, a shared knowledge base and a selfaware community of researchers. It was mainly through global economic and social developments since the turn of the century that scientific work on social innovation evolved into a research area. The recent boost that social innovation (research) has experienced in the European Union can largely be understood as a consequence of the failure of the Lisbon Strategy for Growth and Jobs and the financial crisis of 2008 and 2009: "the long-held belief that economic growth creates employment and wealth that goes on to alleviate poverty has been disproved by recent events, and the time has now come to try new ways of bringing people out of poverty and promoting growth and wellbeing not only for, but also with citizens“" (BEPA, 2010, p. 7).

In 2013, a first systematic attempt to provide an overview of findings of the European Union's research projects on social innovation was undertaken by the Canadian researchers JENSON and HARRISSON. By comparing 17 research projects funded in FP7 and its predecessors FP5 and FP6, the report "focuses on how these projects address 'social innovation' in terms of theory, methodology, policy areas, actors, and level of analysis with the aim of bringing the results to the attention of policymakers, wider groups of stakeholders and the broader public in a comprehensive way" (JENSON \& HARRISSON, 2013, p. 5). Regarding "the increasing demands coming from policymakers and practitioners alike for social innovations and the emerging possibilities for new 
research avenues on social innovation, including in Horizon 2020" (ibid.) such an overview can be of great value. The report also helps to foster "the engagement of the European research community in a continuous exchange of ideas and best practices for analysing social innovation and in the promotion of networking among researchers" (BEPA, 2014, p. 37).

While the report delivers valuable information and points out not only a quantitative, but also a qualitative increase of social innovation research in the European Union in recent years, the authors conclude that some of the most urgent questions remain unanswered: "Although social innovations pop up in many areas and policies and in many disguises, and social innovation is researched from a number of theoretical and methodological angles, the conditions under which social innovations develop, flourish and sustain and finally lead to societal change are not yet fully understood both in political and academic circles. However, in particular in the current times of social, political and economic crisis, social innovation has evoked many hopes and further triggered academic and political debates." (JENSON and Harrisson, 2013, p. 5)

Five years later, we can say that the central questions mentioned by Jenson and Harrisson have been addressed by a new generation of research projects, many of them funded by the European Union (MOULAERT et al., 2017), and by a considerable number of scientific publications. In a collective effort, social innovation research on concepts and theories has further established itself as an autonomous research field with an emerging community of researchers (DOMANSKI \& KALETKA, 2017).

The theoretical and conceptual discussion has intensified, and more attempts have been made to systematise diverse activities, to achieve a better theoretical foundation of the term from different theoretical perspectives and to establish it as an analytical concept with a clearly defined object of study based on interest in knowledge (e.g. PoL \& Ville, 2009; Mulgan, 2012; Moulaert et al., 2013; Cajaiba-Santana, 2013; HowaldT et al., 2014; Pue et al., 2016). Consequently, the social-theoretical foundation of the term for the purpose of a comprehensive social innovation theory - as an important part of a theory of social change or social transformation processes - is more and more becoming the focus of research interest (Franz et al., 2012; Nicholls et al., 2015, KLEIN et al., 2016). Certain progress in the scientific debate on social innovation in recent years has also made the topic more attractive for other (related) research fields. For example, the need for focusing on social innovation can be detected in areas such as Innovation Studies or sustainability and transition research.

At the same time, we must acknowledge that it is still debated in research and practice what exactly makes an innovation a social innovation, and under which conditions can social innovations develop and lead to social change. It is controversially discussed what 'social' means, as is the meaning of 'innovation', its substance, its realisation, its function and its impact. Nevertheless, as Ауов et al. (2016) put it, "the fact that social innovation is contested, conceptually imprecise and used in ways which we may see as disagreeable should not dissuade us from engaging with the concept" (p. 636). 
In the scientific engagement with the topic, normative and non-normative approaches and thus different, partially inconsistent and mainly descriptive definitions are facing each other. In consequence, there are significant issues of interpretation, as well as inconsistent understandings in both political and scientific institutions (DOMANSKI \& KaLETKA, 2017).

Certainly, many research questions still remain unanswered. Nevertheless, the conceptual debate has advanced significantly in recent years, making social innovation a contested concept. Although social innovation cannot be defined in a merely normative way and the sociological perspective emphasises that social innovations are not 'good' per se, but ambivalent in their impact, both normative and analytical concepts can mutually enrich each other regarding the theoretical foundation of the concept. For example, the sociological perspective can help advance the debate towards further conceptualisation and analysis of social innovation as a generative mechanism of transformative social change (ARCHER, 2015).

One of the most prominent areas in which the concept of social innovation has increasingly become a research focus in the social sciences is local and regional development (see e.g. MoulaERT et al., 2005; KROPP, 2015). It is the local and regional context in which challenges such as the effects of the economic crisis, demographic or climate change become directly visible as pressing social demands. And it is the cities and regions where unlikely collaborations emerge to tackle problems when new competences are handed down from national or regional levels without corresponding budget allocations. In Europe, research on the topic of social innovation has been conducted from a regional perspective since the end of the 1980s, particularly by Louis LAVILLE and Frank Moulaert. Their findings in the field of local and regional development on process dynamics of social innovation, especially concerning empowerment dynamics of social movements and initiatives, have significantly contributed to a socio-theoretically sound concept of social innovation. At the same time, regional strategies incorporating social innovation are only beginning to emerge (Rizzo \& DeSERTI, 2017).

Following the assumption that "social innovations are highly embedded in their environment" (CATTACIN \& ZiMmER, 2016, p. 21), the main objective of this paper is to understand what social innovation ecosystems are and how they can be supported and further developed at the regional level. In the following section, the paper focuses on the often disregarded multi-sectoral perspective on social innovation and briefly reflects on the task of developing a scientific concept of social innovation ecosystems. Against the background of the results of the EU-funded research project SI-DRIVE: Social Innovation Driving Force of Social Change (2014-2017), it addresses the main challenges for research and practice when dealing with (regional) social innovation ecosystems. 


\section{Why social innovation ecosystems? A multi-sectoral perspective on social innovation}

Social innovation research does not originate from a systemic concept of innovation (which became dominant in the Innovation Studies in the 1980s), but mainly from rather isolated, often uni-sectoral perspectives or actor-centred approaches. For decades, scientific work in the field of social innovation predominantly focused on social economy and on social entrepreneurship as the main topics. This almost exclusive view fails to recognise other key aspects of a comprehensive concept of social innovation, such as social innovations in the public sector and the role of business economy as well as of academia. At the same time, contributions regarding questions such as "how institutional and social networks and interactions between levels of governance can work to enable or constrain local innovation" (MOULAERT et al., 2013, p. 20) have been important for the development of the research field of social innovation.

The need for better understanding the complexity and systemic character of social innovation can also be stressed by taking a closer look at the field of Innovation Studies. While social innovation research has been strongly characterised by focusing on the third sector as the main societal sector and driver of social innovation or on the social entrepreneur as its protagonist in order to explain how social innovations emerge in societies, concepts such as innovation systems or the triple helix are based upon different components, among them almost always a conceptual operationalisation of drivers, barriers and governance (even if these might be labelled differently). Both concepts recognise appropriate constellations of key actors (i.e. in particular universities, industries and governments) and complex interactions among them as important for developing technological innovations.

Empirical results of the SI-DRIVE project show that multiple types of partners are involved in social innovation initiatives. Findings from the global mapping of social innovations (with 1,005 initiatives mapped) conducted within the project confirm that government and business economy as well as civil society are involved in social innovation initiatives on more or less equal footing, while science and research take up a minor role. Hence, in spite of increasing activity of academia (universities, research centres etc.) in social innovation, this field is still far from having a balanced quadruple helix. The potential of science and research remains largely untapped - a strong contrast to the essential role they play for technological innovations.

\section{Social innovation ecosystems: in search of a concept}

A systemic approach to social innovation focuses on the interfaces of the thus far differentiated and largely separate self-referential societal sectors of state, business, 
civil society and academia, of their corresponding rationalities of action and regulation mechanisms and of the associated problems and problem-solving capacities.

Collaborations between such actors with different sectoral origin can be supported and reconfigured in the sense of sustainability-oriented governance. Here, established steering and coordination patterns are complemented, extended and shaped by aspects like self-organisation, cross-sector co-operation, networks and new forms of knowledge production (HowAldT, Kopp, \& SCHWARZ, 2015). Associated processes of "cross-sectorfertilization" (Phills Jr., Deiglmeier, \& Miller, 2008) and the convergence of sectors (Austin, Gutiérrez, Ogliastri, \& Reficco, 2007) increasingly enable "blended value creation" (EMERSON, 2003).

Such collaborations are picked up by at least two different heuristic models, the quadruple helix (WALLIN, 2010) on the one hand, where government, industry, academia and civil society work together to co-create the future and drive specific structural changes, and the social innovation ecosystem (SGARAGLi, 2014) on the other hand, which also asks for interactions between the helix actors, adds the notion of systemic complexity and looks at both the serendipity and absorptive capacity of a system as a whole. Academic knowledge on social innovation ecosystems is very scarce and the concept remains fuzzy to this day.

The development of a scientific concept of social innovation ecosystems is much more demanding than just trying to adapt concepts such as innovation systems or triple helix to the area of social innovation. The task requires a much better understanding of what social innovation ecosystems are about. One precondition of fulfilling this task is to understand social innovation from a multi-sectoral perspective. In this regard social innovation research could indeed learn from the area of Innovation Studies. Another precondition is to comprehend such ecosystems as systems where social innovations emerge: These innovations are different from technological innovations, which take centre stage in the established concepts mentioned above. Furthermore, the ecosystem perspective goes beyond actor-centred concepts and has to include governance models, potentially supportive infrastructures and even legal and cultural norms which take effect in a specific ecosystem and which make a difference. Therefore, social innovation ecosystems consist of actors from different societal sectors and their environments.

Although it is still emerging as a scientific concept, the social innovation ecosystems approach has already helped to make the notion of environment more prominent for social innovations within the scientific debate. This is especially important regarding the question of how social innovations diffuse and how they are adopted, imitated or scaled. Following Tarde, we focus on the social embeddedness of inventions in a dense network of imitation streams. This allows for a shift in perspective: Unlike SCHUMPETER, for whom the innovator in the social figure of the entrepreneur is the focus of interest, for TARDE (2009) it is inventions which are understood to be the central 'drivers' of social development. In this context, the idea of a social innovation ecosystem helps to overcome a strict actor-centred approach and the strong concentration on the social 
entrepreneur as the key agent of change. The view on the environment in which social innovations are diffused opens up the perspective on different dimensions.

The results of the first global mapping of social innovation initiatives conducted within the project SI-DRIVE provide empirical insights into these environmental conditions social innovations are depending on today. They show that new ways of developing and diffusing social innovations are necessary (e.g. design thinking, innovation labs etc.) as well as the new role of public policy and government for creating suitable framework and support structures, the integration of resources of the economy and civil society as well as supporting measures by science and research.

\section{Challenges for research and practice}

The five key dimensions of social innovation, a methodology used in the SIDRIVE project, help to better differentiate internal and environmental factors initiatives are facing.

\section{Concepts and understanding of social innovation}

The global mapping of SI-DRIVE uncovers countless approaches and initiatives that illustrate the strengths and potentials of social innovations in different parts of the world, with their different economic, cultural, religious and historic backgrounds. Overall, social innovations are gaining in importance not only in relation to social integration and equal opportunities, but also with respect to their innovative ability and future sustainability of society as a whole. At the same time, the understanding of social innovation varies a lot from actor to actor and from ecosystem to ecosystem (HowALDT et al., 2016). For example, while in some ecosystems the understanding of social innovation is mainly influenced by a strong involvement of cooperatives and a dominant role of social economy, in other ecosystems the issue of social inclusion through technological innovations shapes the concept. Also quite common is the lack of a clear understanding of social innovation by those actors who are part of the ecosystem. Better understanding social innovation including its relationship to technological innovation and innovations which strive for economic rather than social value creation would help the actors within the ecosystems work in a more targeted way (Domanski \& KALETKA, 2018).

\section{Objectives and social demands, societal challenges and systemic changes that are addressed}

This research dimension focuses on the desired output and motivation of social innovation and its initiatives. With regard to the different levels at which output is generated, the Bureau of European Policy Advisers (BEPA) suggests that "the output 
dimension refers to the kind of value or output that social innovation is expected to deliver: a value that is less concerned with mere profit, and including multiple dimensions of output measurement" (BEPA, 2010, p. 26). In this understanding, social innovations

- "respond to social demands that are traditionally not addressed by the market or existing institutions and are directed towards vulnerable groups in society [...],

- tackle 'societal challenges' through new forms of relations between social actors, [...] respond to those societal challenges in which the boundary between social and economic blurs, and are directed towards society as a whole [...],

- or contribute to the reform of society in the direction of a more participative arena where empowerment and learning are both sources and outcomes of well-being" (BEPA, 2010, p. 29).

The results of SI-DRIVE's global mapping reveal that actors of innovative projects and initiatives increasingly try to address social needs and societal challenges instead of focusing primarily on economic success and profit. The need to respond to a specific societal challenge or a local social demand are by far the main motivation and trigger for initiating and running a social innovation. More than $60 \%$ of the initiatives started from this perspective (HowALDT et al., 2016).

As the mapping reveals, there is an abundance of approaches and initiatives exploiting the strengths and the potential of social innovation in order to support societal integration through education and poverty reduction, to implement sustainable consumption patterns or to manage demographic change. However, social innovations do not only become increasingly important for ensuring social cohesion and equal opportunities, but also for the innovative capacity and resilience of companies and society as a whole (HowALDT et al., 2016).

\section{Actors, networks and governance}

Who are the actors who shape social innovation ecosystems? At first glance, the answer seems quite obvious: NGOs and NPOs, business companies, social enterprises, public authorities, universities and research centres, just to mention some of them. However, it is not always easy to identify what type of organisation is involved in social innovation, as many social innovation actors are hybrid organisations (HowALDT et al., 2016). Another challenging aspect of working in ecosystems is that many actors are actively participating in social innovation initiatives without using the term 'social innovation' and often without even knowing that they are working on social innovations. While social innovations may play an important role in a national or regional ecosystem, an explicit focus by actors is often missing. It is the task of research to consider all relevant actors, which requires the careful study of an ecosystem far beyond the usual suspects (DOMANSKi \& KALETKa, 2018). 
Moreover, a true challenge for both research and practice has to do with the development of new governance models for social innovation ecosystems. Regarding the importance of empowerment, co-creation and citizen involvement for social innovation, traditional patterns and mechanisms seem obsolete. Against this background, SGARAGLI's approach to social innovation ecosystems in terms of "a paradigm shift where grassroot, bottom-up, spontaneous movements and communities of change are shaping new ecosystems" (2014, p. 9) as well as regarding the "replacement of existing governance models with ones that are more open, inclusive and participatory" (ibid.) opens up a different perspective which needs to be explored through empirical studies.

\section{Process dynamics}

Questions about transferability and scalability within a given or to another ecosystem dominate the social innovation discourse. Scaling in terms of different modes of organisational growth is a typical way of doing this. While scaling is a more prominent strategy within a given ecosystem, transfer and adaptive replication more often takes place in a different setting, which helps to reach completely new target groups (HowALDT et al., 2016). The initiating actors - the social entrepreneur, the project manager, the activist, the group, the network and so on - have a motivation, intention or a strategy to disseminate their solution for a social problem. And there are further activities an actor can initiate in order to overcome the limits of organisational growth. The table below shows the different modes of scaling or dissemination strategies that were discussed in the Critical Literature Review of SI-DRIVE (DAVIES, 2014).

\section{Resources, capabilities and constraints}

Social innovation initiatives are enabled or inhibited through different types of resources, capabilities and constraints, depending on the co-operation of actors, (supporting) networks, cross-sector triple and quadruple helix collaborations, combinations of knowledge backgrounds, user involvement and institutional conditions. They are closely related to the social innovation ecosystem and infrastructure for social innovations. Resources (financial or other) for social innovation ecosystems are definitely not a big issue on most policy-makers agendas. Many ecosystems are poor in terms of resources available for social innovations: Funds are scarce, experts are few and far between and knowledge is missing. SI-DRIVE's global mapping reveals that lack of funding is the biggest barrier for social innovators and that their own resources represent their main financial source (HowALDT et al., 2016). However, it is about much more than money. Social innovation ecosystems can only develop their full potential, if there are people who have the necessary skills to work in this area. Here, universities could play an important role. At the same time, developing capabilities for social innovation ecosystems is a key task for actors from all societal sectors (DOMANSKI \& KALETKA, 2018). 
Table 1: Summary of Main Scaling Strategies (DAvies 2014)

\begin{tabular}{lll}
\hline Approach & Strategy & Overview \\
\hline Replication & 'Scaling out' & $\begin{array}{l}\text { Organisations attempt to replicate their social } \\
\text { innovation in other geographical areas }\end{array}$ \\
\cline { 2 - 3 } & 'Scaling up' & $\begin{array}{l}\text { Organisations attempt to affect a wider system } \\
\text { change by tackling the institutional causes of a } \\
\text { problem }\end{array}$ \\
\cline { 2 - 3 } & Mission networks & $\begin{array}{l}\text { A social entrepreneur abandons traditional aspects } \\
\text { of organisational control (brand, intellectual } \\
\text { property, etc.) to influence and create other 'change } \\
\text { makers' within the system }\end{array}$ \\
\hline Non-replication & Open source & $\begin{array}{l}\text { The core intellectual property of the innovation or } \\
\text { organisation is turned into an open source tool for } \\
\text { others to take up }\end{array}$ \\
& Other (less explored & $\begin{array}{l}\text { Including: } \\
\text { Affiliation with new partners } \\
\text { Dotential strategies) } \\
\end{array}$ \\
& $\begin{array}{l}\text { Working towards changing policy environments } \\
\text { Social movement building }\end{array}$ \\
\hline
\end{tabular}

\section{Conclusions and outlook}

The ecosystems of social innovation are in different stages of development across Europe and beyond. In all countries, "there are a number of important factors enabling the development of social innovation, including important support and impetus from the EU" (Boelman \& Heales, 2015, p. 7). The status of the social innovation activities differs in the different world regions regarding the existence of a (shared) understanding of social innovation, the dissemination of the initiatives, the societal challenges addressed, the actors involved and more. The societal and governance systems in which the social innovations are embedded are complex and the problems addressed are deeply rooted in multifaceted societal and structural issues. At the same time, many initiatives are small in scale: Only a minority of social innovations leave the narrow context of the initiative and the local or regional level, and where they do they mainly scale within their own initiative. Therefore, an important task for future research is not only to better understand social innovation ecosystems themselves (e.g. along the different dimensions presented above), but also to explore connections between ecosystems which would facilitate the diffusion of social innovations. 


\section{References}

Archer M. S. (2015), Generative Mechanisms Transforming the Social Order. Switzerland, Springer International Publishing.

Austin J.E., Gutiérrez R., Ogliastri E., \& Reficco E. (2007), Capitalizing on convergence. Stanford Social Innovation Review 5(4), pp. 24-31.

Ayob M., Teasdale S. \& Fagan K. (2016), How Social Innovation 'Came to Be': Tracing the Evolution of a Contested Concept. Journal of Social Policy 45(4), pp. 635-653.

Boelman V. \& Heales C. (2015), Social Innovation Strategies - Regional Report. D3.6 internal report.

Bureau of European Policy Advisers (BEPA), (2010), Empowering people, driving change, social innovation in the European Union. http://ec.europa.eu/DocsRoom/documents/13402/ attachments/1/translations/en/renditions/native [Last accessed on 20.08.2017]

Bureau of European Policy Advisers (BEPA), (2014), Social Innovation - A Decade of Changes. Luxembourg, Publications Office of the European Union.

Cajaiba-Santana G. (2014), Social Innovation: Moving the field forward. A conceptual framework. Technological Forecasting \& Social Change 82, pp. 42-51.

CATtacin S., \& Zimmer A. (2016), Urban governance and social innovations. In: Brandsen T., Cattacin S., Evers A., \& Zimmer A. (eds.), Social Innovations in the Urban Context. Heidelberg, New York, Dordrecht, London, Springer International Publishing, pp. 21-44.

Davies A. (2014), Social Innovation Process and Social Entrepreneurship. In: Howaldt J., Butzin A., Domanski D. \& KaletKa C. (eds.), Theoretical approaches to social innovation: A critical literature review. A deliverable of the project Social Innovation: Driving Force of Social Change (SI-DRIVE). Dortmund, Sozialforschungsstelle, TU Dortmund University.

Domanski D. \& KaletKa C. (2017), Social Innovation Research on Concepts and Theories. In: Domanski D. \& KaletKa C. (eds.), Exploring the Research Landscape of Social Innovation. A deliverable of the project Social Innovation Community (SIC), Dortmund, Sozialforschungsstelle, TU Dortmund University, pp. 11-30.

Domanski D. \& KaletKa C. (2018), Social Innovation Ecosystems. In: Howaldt J., KaletKa C., SchröDER A., \& ZIRngIEBL M. (eds.), Atlas of Social Innovation: New Practices for a Better Future. Dortmund, Sozialforschungsstelle, TU Dortmund University.

EMERson J. (2003), The blended value map. Integrating social and financial returns. California Management Review 45(4), pp. 34-51.

Franz H.-W., Hochgerner J., \& Howaldt J. (eds.), (2012), Challenge Social Innovation: Potentials for Business, Social Entrepreneurship, Welfare and Civil Society. Berlin and New York, Springer.

Howaldt J., Butzin A., Domanski D., \& KaletKa C. (2014), Theoretical Approaches to Social Innovation - A Critical Literature Review. A deliverable of the project: Social Innovation: Driving Force of Social Change (SI-DRIVE). Dortmund, Sozialforschungsstelle, TU Dortmund University.

Howaldt J., Kopp R. \& Schwarz M. (2015), On the theory of social innovations: Tarde's neglected contribution to the development of a sociological innovation theory. Weinheim, Beltz Juventa. 
Howaldt J., Schröder A., Kaletka C., Rehfeld D., \& Terstriep J. (2016), Mapping the World of Social Innovation: A Global Comparative Analysis across Sectors and World Regions. A deliverable of the project Social Innovation: Driving Force of Social Change (SI-DRIVE). Dortmund, Sozialforschungsstelle, TU Dortmund University.

Jenson J., \& Harrisson D. (2013), Social innovation research in the European Union. Approaches, findings and future directions. Brussels, European Commission.

Klein J.-L., Camus A., Jetté C., Champagne C., \& Roy M. (2016), La Transformation Sociale Par L'innovation Sociale. Québec, Presses de l'Université du Québec.

Kropp C. (2015), Local Governance - Modewort oder wichtiger Ansatz für die Zukunft ländlicher Räume? In: Franke S., Miosga M., \& Schöbel-Rutschmann S. (eds.), Impulse zur Zukunft des ländlichen Raums in Bayern. München, Bayerische Akademie Ländlicher Raum e.V., pp. 31-36.

Moulaert F., MacCallum D., Mehmood A., \& Hamdouch A. (eds.), (2013), The International Handbook on Social Innovation. Collective Action, Social Learning and Transdisciplinary Research. Cheltenham, Edward Elgar Publishing.

Moulaert F., Martinelli F., Swyngedouw E., \& GonzÁlez S. (2005), Towards alternative model(s) of local innovation. Urban Studies 42(11), pp. 1969-1990.

Moulaert F., Mehmood A., MacCallum D., \& Leubolt, B. (2017), Social Innovation as a Trigger for Transformations - The Role of Research. Brussels, European Commission.

Mulgan G. (2012), Social Innovation Theories: Can Theory Catch Up with Practice? In: Franz H.-W., Hochgerner J., \& Howaldt J. (eds.), Challenge Social Innovation. Potentials for Business, Social Entrepreneurship, Welfare and Civil Society. Berlin and New York, Springer, pp. 19-42.

Nicholls A. \& Ziegler R. (2015), An Extended Social Grid Model for the Study of Marginalization Processes and Social Innovation. CRESSI working papers. University of Oxford.

Phills Jr. J.A., Deiglmeier K., \& Miller D.T. (2008), Rediscovering Social Innovation. Stanford Social Innovation Review 6(3), pp. 34-43.

Pol E. \& Ville S. (2009), Social innovation: Buzz word or enduring term? The Journal of SocioEconomics 38, pp. 878-885.

Pue K., Vandergeest C., \& Breznitz D. (2016), Toward a Theory of Social Innovation. University of Toronto.

Rizzo F., \& Deserti A. (2017), Cities and regional development. In: Domanski D., \& Kaletka C. (eds.), Exploring the Research Landscape of Social Innovation. A deliverable of the project Social Innovation Community (SIC), Dortmund, Sozialforschungsstelle, TU Dortmund University, pp. 83-106.

Sgaragli F. (2014), Enabling social innovation ecosystems for community-led territorial development. Rome, Fondazione Giacomo Brodolini.

TARDE G. (2009), Die Gesetze der Nachahmung. Frankfurt am Main, Suhrkamp.

Wallin S. (2010, October), The co-evolvement in local development - From the triple to the quadruple helix model. Paper presented at Triple Helix VIII, Madrid. http://www.leydesdorff. net/th8/TRIPLE\%20HELIX\%20-\%20VIII\%20CONFERENCE/PROCEEDINGS/0110 Wallin Sirkku O-104/triple\%20helix\%20Wallin\%20final.pdf [Last accessed on 20-082017] 


\section{Table}

Table 1: Summary of Main Scaling Strategies 125 